\title{
Pedagogical Model of Preservice Teachers Social Adaptation to the Future Professional Activity
}

\author{
Evgeniya V. Gutman ${ }^{1} \&$ Rasilya R. Nurmieva ${ }^{1}$ \\ ${ }^{1}$ Kazan Federal University, Kazan, Russia \\ Correspondence: Evgeniya V. Gutman, Kazan Federal University, Kazan, Russia. E-mail: mega.sppa@mail.ru \\ Received: July 17, 2019 \\ Accepted: October 10, 2019 \\ Online Published: October 28, 2019 \\ doi:10.5430/ijhe.v8n7p17 \\ URL: https://doi.org/10.5430/ijhe.v8n7p17
}

\begin{abstract}
The article is dedicated to the students' social adjustment to acknowledged informative exercises problems. The study uses a modeling method to build preservice teachers social adaptation pedagogical model. The model comprises a list of operations contributory to successful students social evolution to instructional activities. Students' successful conversion to professional activity is permissible under the status of the university, specially organized work, which is focused on the lecturer teaching student composition of natures. The article details the university organizational and pedagogical conditions, which will help the cerebral and social restructuring of students' experience and will form an adequate position in the teaching staff. The following means are proposed which increase the social evolution level: the development of curricula which contribute to the professional social adaptation; the educational practice programs improvement; development of a system of integrated psychological and pedagogical support in the learning process; the organization of the psychological and pedagogical training.
\end{abstract}

Keywords: social adaptation, pedagogical model, student, professional activity, university, educational process

\section{Introduction}

The system of higher professional education at the present stage is focused on meeting the needs of the labor market and the specific needs of employers, as the requirements for the specialists learning experience increase; external environment, social, economic and other factors are changing; competition in the labor market is becoming tougher, new professions and specializations are emerging; the market for educational services is growing, consumers (students and their parents) are becoming more demanding. In this regard, there is a need to prepare such a student who will meet all these requirements.

In modern psychological, pedagogical and methodological knowledge, there are many concepts and models for the development of future specialists' professional image, among which the adaptation of university graduates to professional activity problem is highlighted. Issues relating to the practice-oriented teacher training are reflected in the works of both Russian and foreign scholars (V. Griffiths, A. Castling,J. Petty,P. Ramsden,I. Reece,W. Robinson, D.Fish and others). Many researchers note the teachers professional activity is one of the most intense types of social activity (L.M. Abolin, L.M. Mitina, S.V. Subbotin), adaptation to which begins long before entering the profession directly, but in the course of study at the university, in the process of practice and the study of specially-oriented disciplines. The formation of teacher's social-physiological adaptation is a part of the course of general adaptation problems elaboration, which is becoming more and more of current importance. The abilities and professional activities of an individual are largely predetermined by their adaptability to fulfilling their work and professional responsibilities (Gallagher, Malloy \& Ryerson, 2016; SAFDARI et al, 2013).

Taking into account this fact we are interested indetermining the adaptation process essence in general and adaptation to the professional and educational activities in particular. Consideration of adaptation as a certain stage of pedagogical education implies an interdisciplinary level taking into account philosophical, historical, social, psychological, pedagogical, professional and other aspects. The need for professional adaptation is actualized in conditions of a significant change in human activity, transformations in social environment. We share the point of view which defines socio-psychological adaptation as an interaction between the individual and the social environment, leading to the correct correlation of the goals and values of the individual and the group, noting adaptation occurs when the social environment contributes to the individual needs and aspirations realization (E.F. Zeer). Under the professional adaptation of the teacher personality is understood the process of initiation to the professional activity, working 
conditions, new team, improving the ways of inclusion in the pedagogical work, the ability to realize in it. This allows imagining the complexity of the future specialists' adaptation to the chosen profession, to construct preparation process for professional and pedagogical activity correctly. Its complexity is also manifested in the fact that the adaptation period is of great importance for the entire future teacher professional activity, and this problem solution is important both for every future teacher, and for society as a whole. At the subjective level, it is expressed in satisfaction from work, positive self-perception and experiencing positive emotions associated with both professional environment as a whole and its separate elements (object of labor, methods, results, social environment) (Terry, 2016; Abayeva, 2018).

\section{Materials and Methods}

When researching this issue, we operated our understanding of specifics of adaptation and emotional aspect of adaptability of students to their future professional activity, which were studied in papers of many psychologists; we have also studied and considered students' age specifics which are described in (Galamba, 2016). Pedagogical adaptation is a complex and diverse process of interaction between human and environment which contains new structural and dynamic characteristics (Bannister, 2016; Marbán \& Mulenga, 2019; Lobão \& Pereira, 2016). The main goal of our research is to develop a pedagogical model of students' social adaptation to professional activity. To implement the proposed model, we have developed a "Psychological and pedagogical workshop", containing a variety of psychological and pedagogical materials, allowing to comprehend the features of the teacher's professional activities, to know oneself, this course motivate students to do their best work, it is logically connected to the basic theoretical pedagogical and psychological disciplines, as well as pedagogical practicum; and optional course "Adaptation to professional activities". This discipline refers to the subjects of professional training and is aimed at enhancing personal and socio-psychological adaptation to the future professional activities of teachers and educators on solving professional and pedagogical tasks. The need to develop the course "Adaptation to professional activities" is due to the fact that: firstly, in academic disciplines is not fully represented the practical training module which promotes adaptation to professional activity, and, secondly, in the professionally-oriented disciplines, the practical training module does not take into account the motivational mechanisms of adaptation to the future profession. The teacher acts as adviser and facilitator, not as an authority dispensing right answers.

This course allows developing the following competencies:

- willingness to apply theoretical and practical knowledge in the field of social adaptation to professional activities;

- be able to adapt to the changing conditions of professional activity;

- be able to apply this knowledge to explain the pedagogical process facts and phenomena, to develop interests in professional field.

The students should know:

- main categories and concepts related to human adaptation;

- social adaptation theoretical aspects;

- patterns, mechanisms and conditions of students social adaptation to professional activities.

Student is able to:

- distinguish between the person basic mental states;

- $\quad$ analyze own mental states;

- $\quad$ apply methods of mental self-regulation in professional activities and everyday life.

\section{Results}

We determine the composition (structure) of our prescriptive pedagogical model getting into account the nature and specifics of pedagogical exercises, trade mission, its use in society; thing of action; expert information, works; exercises, ways of acting, technologies; product of the enterprise (or its result); subjective qualities desired for the active institutional activities, communication, professional and personal growth and self-development (Nosko, 2009). The following principles are at the model base: principle humanization of education, personal agency, consciousness and creative activity, professional direction, reflection, interiorization, and interaction dialogization. Teaching is one of the most delightful and exciting of all human activities when it is done well and that it is one of the most humiliating and tedious when it is done poorly (Ramsden, 2004; Selomo \& Govender, 2016).

In this regard, the university has the following objectives: 
- create organizational and pedagogical conditions which will help the psychological and social restructuring of students' experience and help to form an adequate position in the teaching staff;

- form a high level of students professional competence;

- develop the necessary personal qualities which contribute to successful social adaptation to the profession;

- $\quad$ raise interest and form value attitude to the chosen profession.

Students social adaptation will be more successful if the following conditions are met:

- $\quad$ training programs, which are enhanced by professionally-oriented content will be included in the educational process;

- $\quad$ organization of teaching practicum which provides social adaptation to the profession;

- $\quad$ system of complex psychological and pedagogical students support development in the learning process;

- $\quad$ psychological and pedagogical trainings organization which promote the improvement of students' professional competence (Vinnikova et al., 2017).

Teaching practicum plays an important role in social adaptation to professional activities. The teaching practicum is an exciting part of the Bachelor of Education program because it is the time when teacher candidates put theory into practice alongside an experienced professional teacher. Preservice teachers tend to value more highly their interactions with practicing teachers. It highlights a need for greater sharing of expertise that would enable trainee teachers to make connections between theory and practice. Lazareva M.V. notes that for the effective teaching practicum implementation in the context of the activity-competence approach, it is necessary to develop an assist model for professional development in educational institutions of higher education. This model should take into account the tasks, directions and content of students' activities, the conditions for organizing their teaching practicum, the criteria for evaluating the level of professional preparation for practical teaching activity (Lazareva, 2009). We have included special tasks in the content of practicum training programs, which provide a choice of the content and forms of students' work in practicum, develop the professional competence, integrate the acquired knowledge for the performance of professional duties. The implementation of a full-fledged teaching activity implies that the teacher candidate has the ability to analyze and adequately evaluate own work. Proceeding from this, the preservice teacher needs to master the methods of self-diagnosis, which will contribute to the improvement of teaching skills as well as the whole educational process. Our university has developed a system of complex psychological and pedagogical support for students in the process of social adaptation to professional activities. The system consists of compulsory developmental and diagnostic procedures carried out within a month after undergoing a teaching practicum with students of $4-5$ courses.

At the first stage, after teaching practicum information was collected and analyzed. It allows determining the level of students social adaptation to professional activities. To solve this problem we have adapted R.V. Gurina's technique (Gurina, 2008). The results we received brought us to the conclusion that the overwhelming majority of the studied students (57\%) showed average level of adaptability. High rates which show the readiness to independently overcome difficulties in communication and fulfill creative possibilities were detected among $30 \%$ of the participants. And $13 \%$ of the investigated student sample showed inability to change together with the social environment, tendency to use behavioral patterns in relations and interaction with the people around, inflexibility in situations which require fast pedagogic reaction.

Students with a high level of adaptability quickly got used to the working hours, the routine and the new requirements of the educational institution. The students prepared successfully for all the events held in the educational institution, implemented the teaching practicum tasks, they faced up to the teachers' remarks speculatively and reflexively, came into contact with all participants of the pedagogical process easily. They stated that "productivity of the practicum taken in the school enables them to understand the qualifications that a teacher must have". Opportunities and chances that the students have in the school let them have rich variety of experiences related to communication with people. They are in a positive choice.

Students with an average level of adaptability adapted to the teaching practicum longer (from one to two weeks). This is a period of uncertainty and confusion. They experienced considerable difficulties in the practicum process, did not cope with all the tasks. They were sensitive about the teachers' recommendations and remarks; they did not come into contact with all the participants in the educational process. However, after consulting with the practicum supervisor, they managed to overcome most of the difficulties. But they stated that they could not benefit from the 
teaching process and they did not gain sufficient teaching experience, the rate of self-motivation and self-control over emotional states did not surpass.

Students with a low level of adaptability were unable to get used to the work pattern until the practicum end. Another problematic area of student practicum is the development of professional values and understanding of pupils' and colleagues' needs. They were stressed, did not seek to come into contact with students and teachers. It is highlighted that preservice teachers' thoughts related to teaching professions can change after they start in teaching-learning process. Students were more likely to agree with questionnaire statements such as 'Often I find myself wondering whether the work I am doing here is really worthwhile' and 'When I look back, I sometimes wonder why I ever decided to come here'.

At the third stage, after the diagnosis and students distribution, the supervisors of the teaching practicum develop a single line of interaction between university specialists and students with a low level of adaptability in groups and individually. Individual counseling is often more effective because:

- allows identifying the student individual characteristics: competences, abilities, interests, personality;

- helps the student self-knowledge and self-determination;

- promotes the sharing of experiences between teachers and students;

- allows outlining an individual way to overcome hurdles of professional activity;

- helps to assess the student professionally important qualities and to orient to the development pathway which will contribute to the success, the most effective knowledge using; to have the opportunity to realize his or her fullest potential.

The work being done contributes to reducing the number of students expelled from the university, helps students feel more comfortable, and increases the number of well-adapted students during subsequent teaching practicum. Also, students are given the opportunity to attend special trainings: team building training, motivation training, and high tolerance for stress training, which are organized as electives in the university educational process. It is proposed to choose courses which contribute to increasing the level of social adaptation to the profession "Psychological and pedagogical workshop" and "Adaptation to professional activities". Knowledge of the individual dynamics and the professional development process and each individual student development, the awareness of their own personal characteristics is an indispensable condition for the psychological assistance in overcoming emerging problems and difficulties. Discussions, more or less formal, among colleagues and/or practitioners and employers about key skills are also included in these courses. Reflection on the main activities students will have to undertake in order to learn assessment methods that will be used to find out whether they have learned them.

During the training, students have the opportunity to:

- to actualize and comprehend the gained knowledge;

- to develop internal, not external motivation, aimed at the student personal growth (Seryi, 2005);

- to acquire certain professional skills quickly and accurately;

- to perceive professional contacts skills in a new way;

- to preserve the student free choice.

\section{Discussions}

Printing projects in the realm of teaching and education received significant consideration in therapy and education. An instance is the examination of the particular behavioral emission of tutor professionally relevant conditions outlined in A. Maslow's research work (Maslow, 1989). It draws 28 behavioral exemplars powerful coach: from crafts to anticipate and disrupt misconduct learner professions to manage intelligent activity by the rules of its genesis to divide their concentration abilities and practice in business identification of children's preferences and character of the baby. In Russia, N.V. Kuzmina, V.A. Slastenin exhibited such role in their investigation, (Kuzmina, 2003, Slastenin, 2004). These producers concentrate on professional where elements on the body and coaches activity are proved scientifically. To date, there are several theoretical ideals of education professionals, developed based on a consideration of phenomenology teaching activities, the features of its operations and individual deputies of the field of pedagogy and education (S.G. Vershlovsky, S.B. Yelkanov, V.A. Kan-Kalik, I.F. Isaev, E.N. Shiyanov, G.S. Sukhobskaya, L.M. Friedman, etc.). Largest of them describe to the projects and the teacher's character (A.O. Prokhorov, A.K. Markova, L.M. Mitina, J. Ravenn etc.), also the period of professional education, that is, focused training in the chosen professional activity and mastering all the ins and outs of professional skill. The psychological criteria for the 
successful completion of this stage is the individual professional self-determination, that is, the formation of an attitude towards yourself as the subject of a chosen activity and professional orientation, which quite clearly reflects attitudes towards the development of professionally significant qualities. K. Rogers considers the main task of the teacher to help the student in his personal growth. Pedagogy, in his opinion, is akin to therapy: it must always take into account physical and mental health, taking into consideration the students individual characteristics, student quality, personal motivation, and the creative qualities formation at each stage of the educational process. The transformation of professional activity, its qualitatively new level, in turn, leads to further individual improvement, development and self-realization, and the changed personality again fills the activity with new content and meaning (Fonarev, 2005).

\section{Conclusion}

Thus, the presented pedagogical model can be considered optimal: it has the main components of the pedagogical process; it can lead to the expected result - to the valuable attitude formation to the teacher's profession among university students, as well as to ensure their social adaptation to future professional activities. The activity of the subjects of the educational process is aimed at the students entry, inclusion and adaptation into the profession through the competencies formation and development, personal qualities and value orientations, the personality social and professional development, building an individual educational route, the creative potential realization, the professional independence development, interconnection and interdependence of educational and extracurricular processes. Since the pedagogical profession is socially adaptable not only works with people, but also gives the opportunity socially adapt to life then before Pedagogical Institute there is a primary task: to organize educational process in such a way as to satisfy social, professional and emotional student needs.

\section{Acknowledgements}

The work is performed according to the Russian Government Program of Competitive Growth of Kazan Federal University.

\section{References}

Abayeva, G. (2018). Modern teacher role for increasing the students' competence in pedagogical specialty. Opción, 34(85-2), 415-440.

Bannister, N. A. (2016). Breaking the spell of differentiated instruction through equity pedagogy and teacher community. Cultural Studies of Science Education, 11(2), 335-347. https://doi.org/10.1007/s11422-016-9766-0

Fonarev, A. R. (2005). Psychology of the formation of the personality of a professional: Proc. Benefit.- M.: Publishing House of the Moscow Psychological and Social Institute, 240.

Friedman, L. M. (2001). On the concept of school psychological services. Questions of psychology, 1, 97-106.

Galamba, A. (2016). Conflicting interpretations of scientific pedagogy. Science \& Education, 25(3-4), 363-381.https://doi.org/10.1007/s11191-016-9822-x

Gallagher, M. J., Malloy, J. \& Ryerson, R. (2016). Achieving excellence: Bringing effective literacy pedagogy to scale in Ontario's publicly-funded education system. Journal of Educational Change, 17(4), 477-504.https://doi.org/10.1007/s10833-016-9284-6

Gurina, R. V. (2008). How to measure a professional competency? Higher Education in Russia, 10, 82-89.

Kan-Kalik, V. A. (2000). Teacher creativity. Education Press, 140.

Kuzmina, N. V. (2003). Professionalism personality. In the Proceedings of the international scientific and practical conference, Nizhny Novgorod, 6-9.

Lobão, J. \& Pereira, C. (2016). Looking for Psychological Barriers in nine European Stock Market Indices., Dutch Journal of Finance and Management, 1(1), 39.https://doi.org/10.20897/lectito.201639

Lazareva, M. V. (2009). Activity-competence approach to the organization of educational practice. Secondary vocational education, 3, 35-36.

Marbán, J. M. \& Mulenga, E. M. (2019). Pre-service Primary Teachers' Teaching Styles and Attitudes towards the Use of Technology in Mathematics Classrooms. International Electronic Journal of Mathematics Education, 14(2), 253-263. https://doi.org/10.29333/iejme/5649

Markova, A. K. (1996). Psychology professionalism. International Humanitarian Fund "Knowledge”, 312.

Maslow, A. (1989). Self-actualization (Psychology of Personality. Tests). Moscow Press, 228. 
Mitina, L. M. (2004). Psychology of work and professional development of teachers. Academy Press, 320.

Nosko, I. V. (2009). Competent model of the graduates Bachelor of Pedagogy, Far Eastern State University Press, 187.

Prokhorov, A. O. (2014). Mental state representation: Spatiotemporal characteristics. American Journal of Applied Sciences, 11, 866-871. http://doi.org/10.3844/ajassp.2014.866.871

Ramsden, P. (2004). Learning to Teach in Higher Education. London and New York: Routledge Falmer, 305. https://doi.org/10.4324/9780203507711

SAFDARI, M., ARAB, B. A. \& BAGHERI, G. A. (2013). Realization of economic justice through teleworking. UCT Journal of Management and Accounting Studies, 1(1), 11-13.

Selomo, M. R. \& Govender, K. K. (2016). Procurement and Supply Chain Management in Government Institutions: A Case Study of Select Departments in the Limpopo Province, South Africa. https://doi.org/10.20897/lectito.201637

Seryi, A. V. (2005). Formation of practical competence psychologist. Higher education in Russia, 5, 63-66.

Slastenin, V. A., Isaev, J. F. \& Shiyanov, E. N. (2002). Pedagogy, Publishing Center Academy, 576.

Slastenin, V. A. (2004). Methodology of educational work, Academy Press, 144.

Sukhobskaya, G. S. (2002). The concept of social maturity and psychological human development in the context of andragogy. New Knowledge, 4, 17-20.

Terry, K. P. (2016). Review of integrating technology and pedagogy: Improving teaching and learning in higher education. Tech Trends, 60(4), 402-403.https://doi.org/10.1007/s11528-016-0065-0

Turning Education Structures in Europe. (2008). Retrieved from URL:http://www.unideusto.org/tuningeu

Vershlovsky, S. G. (2010). Adult education system as is forecasting. Herald of Academic Institute of Adult Education of the Russian Academy of Education, 1, 16-21.

Vinnikova, M. N., Fakhrutdinova, A. V., Dulmukhametova, G. F. \& Shamsutdinova, D. V. (2017) Modern use of the pedagogical technology «team-teaching « in the training of teacher candidates. QUID-INVESTIGACION. Special Issue N1-SSN: 1692-343X, Medellín-Colombia, 767-772.

Yelkanov, S. B. (2006). Fundamentals of Professional Self-Teach Future Shipment. Education Press, 180. 